\title{
THE FORECASTING BUDGET REVENUES IN ARDL APPROACH: A CASE OF UZBEKISTAN
}

\author{
candidate of physical and mathematical Sciences, Professor Fayziev R. A. \\ candidate of economic Sciences, associate Professor Khudoykulov S. K. \\ Rajapov Sh. Z. \\ Axmadjonov A. A. \\ Uzbekistan, Tashkent, \\ Tashkent state University of Economics
}

DOI: https://doi.org/10.31435/rsglobal_ijite/31012019/6330

\section{ARTICLE INFO \\ Received 18 November 2018 Accepted 08 January 2019 Published 31 January 2019}

KEYWORDS

ARDL,

bound test, cointegration, forecasting, taxpayers.

\begin{abstract}
This paper contribute to the forecasted total budget revenues in Uzbekistan. It is aim to investigate long run and short run relationship between number of registered company, total number of taxpayers and forecasted total budget revenues from 1998 and 2017. More specifically, this dynamic relationship using bounds testing approach to co integration and the ARDL model. The main empirical findings indicate the existence of directional relationship between the number of registered company and forecasted total budget revenues in short run and long run. This mean that increase the number of registered company leads to go up forecasted total budget revenues. However, a unidirectional relationship between the total number of taxpayers and forecasted total budget revenues are confirmed in the long run and short run.
\end{abstract}

Citation: Fayziev R. A., $\quad$ Khudoykulov S. K., $\quad$ Rajapov Sh. Z., Axmadjonov A. A. (2019) The Forecasting Budget Revenues in ARDL Approach: a Case of Uzbekistan. International Journal of Innovative Technologies in Economy. 1(21). doi: 10.31435/rsglobal_ijite/31012019/6330

Copyright: (C) 2019 Fayziev R. A., Khudoykulov S. K., Rajapov Sh. Z., Axmadjonov A. A. This is an open-access article distributed under the terms of the Creative Commons Attribution License (CC BY). The use, distribution or reproduction in other forums is permitted, provided the original author(s) or licensor are credited and that the original publication in this journal is cited, in accordance with accepted academic practice. No use, distribution or reproduction is permitted which does not comply with these terms.

1. Introduction. The current tax policy in Uzbekistan is becoming one of the key factors affecting the pace of economic growth. The one of the reason that the country's leadership pays great attention to improving the tax policy and tax administration. In particular, many taxes reformations were expected and worked out from the moment of the release of the President's Decree "On measures to radically improve tax administration, increase the collection of taxes and other mandatory payments" of July 18, 2017. It is known that the Strategy of Action on the five priority development directions of the Republic of Uzbekistan in 2017-2021 provides for a consistent simplification of the taxation system, reducing the tax burden by expanding the taxable base. As noted in the Decree of the President of the Republic of Uzbekistan dated July 18, 2017 No.UP5116 "On Measures for the Basic Improvement of Tax Administration, Increasing the Collection of Taxes and Other Mandatory Payments," to assess the objectivity and validity of the forecast of the State Budget revenues. Today, the main problem is that the current situation raises the need for the tax system to introduce methods that are more efficient. In particular forecasting ensuring is reliable forecasting of tax revenues to the budget.

Forecasting taxes require extensive econometric, mathematical analysis and research. In this regard, there are many models to be used in the world practice. It is important to note that further growth of econometric macroeconomic models that famous on autoregressive of the medium deviation model of ARIMA (autoregressive integrated moving average) are dependent on creation and its extensive application by economists and mathematicians Bocks and Johnsons. In the 60-70th years of the 20th century, model of AutoRegressive Integrated Moving Average (ARIMA), the autoregressive 
model (AR) and the transverse functional model were public. This ARIMA model is used to forecast short-term revenues.

One of the last models of forecasting taxes is micro imitative models. Micro imitative models are widely used in the implementation of short-term forecasts in the world practice, including for forecasting tax revenues from tax payments by individuals. The essence of this is that, in the case of a large number of individuals, the micro imitative model has proven to be more accurate in determining the tax revenue over the periods. Tax reporting from taxpayers is a main base, and general trends are identified by using statistical methods in modelling and they are studied dynamically for a specific over the period.

Other models of forecasting taxes is the extrapolation model. It is well known that the extrapolation is a process of acquiring or disseminating. The part of the conclusions based on the observation of some of the phenomena and processes, and in this model of forecasting taxes, as well as its general features, but the endogenous and exogenous phenomenon in the past, it is important to take into consideration the impact of its appearance on its future appearance.

The last a few decades, econometrics models and methods used in the forecasting taxes process of the Republic of Uzbekistan. This including extrapolation methods (exponential grinding, REM, ARIMA), modelling techniques (cross-section, time series, panel, reprinting tax models), etc., are not adequately adjusted to the changing state of the tax system, and in their turn, the methods used in practice are being further improved.

In according to the Decree of the President of the Republic of Uzbekistan of July 18, 2017, "On improvement of tax administration, increasing the collectability of taxes and other payments" and the order "On organizational measures for radical improvement of the tax legislation" of February 13, 2018. These are still necessary to introduce the most advanced and tested forms and methods widely used abroad.

In particular, it is important to introduce effective forms of models and methods that are used in the process of taxation in the context of improving tax administration. Therefore, in the research process, we have been able to achieve relatively effective outcome in the tax system of the Republic of Uzbekistan, based on the model of "Autoregressive Distributed Lag" (ARDL) model, which is currently used as one of the most effective models in the world practice. Today, the smallest squares method employed in practice is not able to provide optimal forecasting parameters, taking into account the rapidly changing processes.

The "Autoregressive Distributed Lag model", which we offer, will enable you to identify a shorter and longer-term outlook that will allow you to apply many factors affecting tax revenue. The advantages of this model are that of direct and indirect impacts on tax revenue, such as the gross domestic product, the number of registered enterprises, the number of taxpayers (tax liabilities), tax exemptions to taxpayers, current debt burden on budget, level, average tax rate, and long-term outlook. The objective of this model is to provide an objective assessment of multi-dimensional impacts in the tax-budgeting system of the republic, and simplification of the forecasting process will increase the objectivity and validity of the final figures. The paper rest of constructed as follows: section 2 indicates literature review. Section 3 describes methodology and data collection. The next section gives the empirical finding, results and conclusion.

2. Literature review. Many researchers have studied on the relationship between FDI and GDP growth with ARDL model the last a few decades. They found a long relationship two variable with together and the outcomes have varied significantly. Other studies have focused on the relationship between consumer energy and incomes. However, the results was build the difference economics structures, which is especially countries studies; in particular, those that are difference stage of the development. The first studies was examined the autoregressive distributed lag (ARDL) approach by Pesaran (1997), and then he continued in those studied by Pesaran et al. (2001). They tested the persistence of the relationship energy, employment and industrial production that found out the long run relationship those chosen variables. One of the most tested method that required variable must be integrated of the first level was developed Engle and Granger (1987). This approach have a process two stage. The first step includes a test cointegration was tested that the regression of one nonstationary variable on another is run and the residual was verified for stationary. Engle and Granger showed that the two variable non-stationary is a stable linear relationship, and then they were tested cointegration test. If variables had cointegration then there was an error correction. The next step was 
examined the error correction which identified short run relationship. This approach had a shortage in multivariate case. Then, Johansen $(1988,1991)$ and Johansen and Juselius (1990) developed this approach and in this approach was more efficient in multirivate regression analysis but this approach became some shortage. The ARDL approach corrected those errors and had some over these other approaches. Ramazan Sariet al. (2008) examined the relationship energy consumption and industrial production through the ARDL model. The finding of the result bound test showed the presence of cointegration between the energy consumption, employment and industrial production. Their result indicated the short run relationship, there was a short run equilibrium, and this paper have important implications for public US energy policy and private sector investment in energy production. Bruce (2006) also studied ARDL model that used causal relationship between immigration and per capital economics growth. It was evident that he found a long run relationship between per capita economic growths to immigration. Besides that, he found out a short relationship with error correction model (ECM) and there was evidence of causality from per capital economic growth to immigration. Nicholas (2009) studied the causal relationship between energy consumption and economic growth in Tanzania. The finding of the result the bound test indicated that there was a stable long run relationship between energy consumption and economic growth. On the other hand, the testing of the causality showed the indirect causal between energy consumption and economic growth. Riadh Briniet al. (2017) examined that there existed a relationship renewable energy consumption, international trade, oil price and economic growth. The study result presented the existence of the bidirectional relationship between renewable energy consumption and international trade in the short-run but there was a unidirectional relationship between renewable energy and oil price, that was evident, that was the short-run. Soo Khoon Gohet al. (2017) studied the relationship between foreign direct investment (FDI), exports, and gross domestic product (GDP) including Asian countries. They studied a new method of ARDL approach that was the bootstrap ARDL. The study result showed that there was a long run relationship between FDI and GDP in selected Asian economics. Besides that, they confirmed that the FDI contributed to help to increase in real income Asian economics. They research indicated that the failure is to find evidence of cointegration the GDP related the dependent variable. Kamiar Mohaddeset al. (2017) tested the relationship among real GDP growth and the ratio of nonperforming loans (NPLs) for example in Italy. The finding of result that there was a growth effect of about 1.2 percent in relationship among real GDP growth and NPL ratios. Mohammad Mafizur Rahman \& Mohammad Abul Kashem (2017) examined the relationship long and short run series, empirical cointregration as well as Granger Causality test between carbon emissions, energy consumption and industrial growth. The study result confirmed that there was a long run cointegration among carbon emissions, energy consumption and industrial production. The industrial production and energy consumption effected positively to the carbon emissions short and long run periods.

3. Methodology. This research tested the long run and short run cointregration in selected variable forecasting taxes with ARDL (autoregressive distributed lag) model. Pesaran et al. (2001) built the ARDL bound testing framework according to this, we also apply ARDL test cointregration that is going to find long run relationship among the variable. The autoregressive distributed lag (ARDL) model is a dynamic single-equation error-correction specification. In general, a three-variable ARDL ( $p, q, r)$ is given as follows:

$$
y_{t}=\sum_{i=1}^{p} \alpha_{i} \mathrm{y}_{t-i}+\sum_{j=0}^{q} \beta_{j} x_{t-j}+\sum_{k=0}^{r} \chi_{k} z_{t-k}+u_{t}
$$

Where, $i, j$ and $k$ are indices of lags: $i=1,2, \ldots, p ; \mathrm{j}=0,1,2, \ldots, q ; k=0,1,2, \ldots, r ; \mathrm{t}$ denotes the time periods $t=1,2, \ldots, T ; y_{t}$ is the dependent variable; $x_{t}$ and $z_{t}$ are the explanatory variables and $u_{t}$ is the i.i.d. disturbance term with a zero mean and a finite variance, $\sigma^{2}$.

We use the theoretical frame work was developed by Pesaran (2001), with the long run cointregration model. Our ARDL model approach to cointegration can be denoted as follows:

$$
\begin{aligned}
& \triangle \log F T B R_{t}=\alpha_{0}+\alpha_{1} \Delta \log \left(F T B R_{t-1}\right)+\alpha_{2} \triangle \log \left(F T B R_{t-2}\right)+\alpha_{3} \triangle \log (N R C)+\alpha_{4} \Delta \\
& \log \left(N R C_{t-1}\right)+\alpha_{5} \Delta \log \left(N R C_{t-2}\right)+\alpha_{6} \Delta \log (T N T)+\alpha_{7} \triangle \log \left(T N T_{t-1}\right)+\alpha_{8} \Delta \\
& \log \left(T N T_{t-2}\right)
\end{aligned}
$$


Where, $\boldsymbol{F T B R}$-Forecasted total budget revenues; $\boldsymbol{N R C}$ - number of registered company; $\boldsymbol{T N T}$ total number of taxpayers.

3.1. Data collection. The study on the ARDL model conduct with cointregration among forecasted total budget revenues and number of registered company, total number of taxpayers. Annual report was collected from the State Taxation Committee of Uzbekistan annul report. The database include the period from 1998 and 2017. The number of observesition for each variable is 20. The variable forecasted total budget revenues in obtained taxes that is sum equivalent. Both number of registered company and total number of taxpayers are number equivalent. Before running ARDL model, we convert into log form all variable in order to equal equivalent. Then, we verify variable that is stationary or non-stationay because ARDL approach requir must be stationay level (10) or stationay first level (11) in selected variable. Then, both variable make ARDL model that find a long run cointregration.

\section{The empirical finding and result.}

\subsection{Unit root test.}

The estimation of the long run coefficient of the ARDL model using equation (2) is based on the three steps. The first step, all variables integration is estimated by unit root test that including the Augmented Dickey-Fuller (ADF) and Phillips-Perron (PP) unit root tests as follow table 1.

Table 1.

\begin{tabular}{|c|c|c|c|c|c|c|}
\hline \multirow{2}{*}{ Variables } & \multicolumn{3}{|c|}{$\mathrm{ADF}$} & \multicolumn{3}{|c|}{ PP } \\
\hline & Intercept & $\begin{array}{l}\text { Intercept } \\
\text { and trend }\end{array}$ & None & Intercept & $\begin{array}{l}\text { Intercept } \\
\text { and trend }\end{array}$ & None \\
\hline$F T B R$ & $-1,5483$ & $-4,0226^{* *}$ & 1,8441 & $-1,6365$ & $-4,0158^{* *}$ & 2,6706 \\
\hline$\triangle F T B R$ & $-6,9155^{* * *}$ & $-6,8943^{* * *}$ & $-5,9598^{* * *}$ & $-11,7454^{* * *}$ & $-18,7519^{* * *}$ & $-5,9598^{* * *}$ \\
\hline$N R C$ & $-0,6357$ & $-3,0176$ & 1,4126 & $-0,1692$ & $-3,0176$ & 3,1592 \\
\hline$\triangle N R C$ & $-5,6260^{* * *}$ & $-5,3983^{* * *}$ & $-4,6730^{* * *}$ & $-5,8082^{* * *}$ & $-5,4479^{* * *}$ & $-4,6369^{* * * *}$ \\
\hline$T N T$ & $-0,0856$ & $-2,9501$ & 1,0689 & 0,15844 & $-2,9543$ & 1,2271 \\
\hline$\triangle T N T$ & $-6,7158^{* * *}$ & $-6.9071^{* * *}$ & $-1,8298^{* *}$ & $-6,3587^{* * *}$ & $-6,7122^{* * *}$ & $-5,4824^{* * *}$ \\
\hline \multicolumn{7}{|c|}{ Test critical values } \\
\hline $1 \%$ & $-3,8573$ & $-4,5715$ & $-2,7080$ & $-3,8573$ & $-4,5715$ & $-2,6997$ \\
\hline $5 \%$ & $-3,0403$ & $-3,6908$ & $-1,9628$ & $-3,0403$ & $-3,6908$ & $-1,9614$ \\
\hline $10 \%$ & $-2,6605$ & $-3,2869$ & $-1,6061$ & $-2,6605$ & $-3,2869$ & $-1,6066$ \\
\hline
\end{tabular}

Notes. $\Delta$ as shown the first difference level. ${ }^{* * *}$ p-value $<0.01 ;{ }^{* *}$ p-value $<0.05 ;{ }^{*}$-value $<0.05$;

Table 1 shows the result both ADF and PP unit root tests that selected all variables nonstationary in their level, but there is stationary all variables in their first difference at $5 \%$ level its level form according to the $\mathrm{ADF}$ and $\mathrm{PP}$ tests.

\subsection{ARDL model selection criteria.}

The first stage of the model selection criteria is to select optimal Akaike Information Criterion (AIC), Schwarz Information Criterion (SIC) and Hannan Quinn criterion (HQ). Table 2 can be as follows: 
Table 2.

\begin{tabular}{|c|c|c|c|c|c|c|}
\hline Model & $\log L$ & AIC* & $\mathrm{BIC}$ & HQ & Adj. R-sq & Model selection \\
\hline 1 & 16.480933 & -0.880110 & -0.438997 & -0.836262 & 0.849802 & $\operatorname{ARDL}(2,2,2)$ \\
\hline 2 & 11.057695 & -0.359729 & 0.032372 & -0.320753 & 0.747302 & $\operatorname{ARDL}(2,2,1)$ \\
\hline 3 & 10.975536 & -0.467710 & -0.124622 & -0.433607 & 0.770363 & $\operatorname{ARDL}(2,2,0)$ \\
\hline 4 & 11.175897 & -0.373635 & 0.018465 & -0.334659 & 0.750791 & $\operatorname{ARDL}(2,1,2)$ \\
\hline 5 & 10.852411 & -0.453225 & -0.110137 & -0.419121 & 0.767012 & $\operatorname{ARDL}(2,1,1)$ \\
\hline 6 & 10.771554 & -0.561359 & -0.267284 & -0.532128 & 0.786168 & $\operatorname{ARDL}(2,1,0)$ \\
\hline 7 & 11.047275 & -0.476150 & -0.133062 & -0.442046 & 0.772293 & $\operatorname{ARDL}(2,0,2)$ \\
\hline 8 & 10.734968 & -0.557055 & -0.262980 & -0.527823 & 0.785246 & $\operatorname{ARDL}(2,0,1)$ \\
\hline 9 & 9.897262 & -0.576148 & -0.331086 & -0.551789 & 0.782753 & $\operatorname{ARDL}(2,0,0)$ \\
\hline 10 & 12.395953 & -0.517171 & -0.125071 & -0.478195 & 0.784113 & $\operatorname{ARDL}(1,2,2)$ \\
\hline 11 & 10.940142 & -0.463546 & -0.120458 & -0.429442 & 0.769404 & $\operatorname{ARDL}(1,2,1)$ \\
\hline 12 & 10.660954 & -0.548348 & -0.254272 & -0.519116 & 0.783368 & $\operatorname{ARDL}(1,2,0)$ \\
\hline 13 & 10.874498 & -0.455823 & -0.112735 & -0.421720 & 0.767617 & $\operatorname{ARDL}(1,1,2)$ \\
\hline 14 & 10.741837 & -0.557863 & -0.263788 & -0.528631 & 0.785419 & $\operatorname{ARDL}(1,1,1)$ \\
\hline 15 & 10.471379 & -0.643692 & -0.398629 & -0.619332 & 0.796942 & $\operatorname{ARDL}(1,1,0)$ \\
\hline 16 & 10.828725 & -0.568085 & -0.274010 & -0.538854 & 0.787602 & $\operatorname{ARDL}(1,0,2)$ \\
\hline 17 & 10.676569 & -0.667832 & -0.422769 & -0.643472 & 0.801785 & $\operatorname{ARDL}(1,0,1)$ \\
\hline 18 & 9.350320 & -0.629449 & -0.433399 & -0.609962 & 0.786136 & $\operatorname{ARDL}(1,0,0)$ \\
\hline
\end{tabular}

Table 2 presents the result optimal lags $\operatorname{ARDL}(2,2,2)$ because AIC is the biggest at $0.880110, \mathrm{BIC}$ is also the biggest at -0.438997 and HQ is the biggest at -0.836262 . According to three criterion rules are chosen the biggest indicators thus the beggist indicators that is optimal model selection. In this case, $\operatorname{ARDL}(2,2,2)$ is optimal model and it is able to detirmine long run cointregration. Then, we run ECM-ARDL $(2,2,2)$ model including dependent variable of $\triangle F T B R$ as follow table 3 .

Table 3. ECM-ARDL model result

\begin{tabular}{|c|c|c|}
\hline Variables & Coefficient & Probability \\
\hline$\Delta \log F T B R_{t-1}$ & -0.309249 & 0.2207 \\
\hline$\Delta \log F T B R_{t-2}$ & -0.430791 & 0.0570 \\
\hline$\triangle \log N R C$ & 7.084715 & 0.0001 \\
\hline$\Delta \log N R C_{t-1}$ & 0.041987 & 0.9801 \\
\hline$\Delta \log N R C_{t-2}$ & 4.274451 & 0.0283 \\
\hline$\Delta \log T N T$ & -2.287929 & 0.0114 \\
\hline$\Delta \log T N T_{t-1}$ & -1.342747 & 0.1924 \\
\hline$\Delta \log T N T_{t-2}$ & -2.579714 & 0.0300 \\
\hline$E C M_{t-1}$ & -0.046401 & 0.0000 \\
\hline $\begin{array}{c}\text { Breusch-Godfrey Serial Correlation LM } \\
\text { Test (p-value) }\end{array}$ & 0.6658 & \\
\hline ARCH test $(p$-value $)$ & 0.4895 & \\
\hline Ramsey RESET Test (p-value) & 0.1035 & \\
\hline Normality test (p-value) & 0.4825 & \\
\hline
\end{tabular}


Table 3 shows that estimated to gain the long-run and short-run coefficients using ARDL approach. The study results in table 2 present that the coefficients realeted to forecasted total budget revenues in logarithm have a long-run and short-run and the number of is significate level 5 percent that total number of tax payers is a negative impact to forecasted total budget revenues. However, the number of registered company effect positively to forecasted total budget revenues and it is significant level 5 percent. More specifically, a 1 percent go up in the number of registered company indicates increase in the forecasted total budget revenues 7,084 percent over the long run and short run. The total number of taxpayer's coefficient of regression found out long run and short run that has a positive impact and statistically significant 5 percent level. This mean that an increase in the total number of taxpayer's by 1 percent and go down in the forecasted total budget revenues by 2,28 percent over the long run and short run. Both number of registered company and total number of taxpayers are significant at the 1 percent level. This study result can be explained by the existence of long run realetionship of two variables. The lag error correction term $\left(\boldsymbol{E} \boldsymbol{C} \boldsymbol{M}_{t-1}\right)$ indicates the speed of adjustment the forecasted total budget revenues that it is long-run equilibrium following a shock. The coefficient of -0.464018in negative and statistical significant at the 1 percent level. This study results show the persistence of a stable long run cointregration among $\triangle \log N R C, \triangle \log T N T$ and $\triangle F T B R$. This mean that by 4,6 percent in next year is corrected a deviation from the long-run equilibrium level of total budget revenues.

The diagnostic tests of the ARDL model confirm that there is no serial correlation (Breusch-Godfrey Serial Correlation LM Test), heteroscedasticity (ARCH test), the functional errors is specified (RESET test) and the normality of the residuals. Then, we apply the cumulative sum (CUSUM) and cumulative sum squares (CUSUMS) of recursive residuals tests in order to check the robustness of the results in figure.

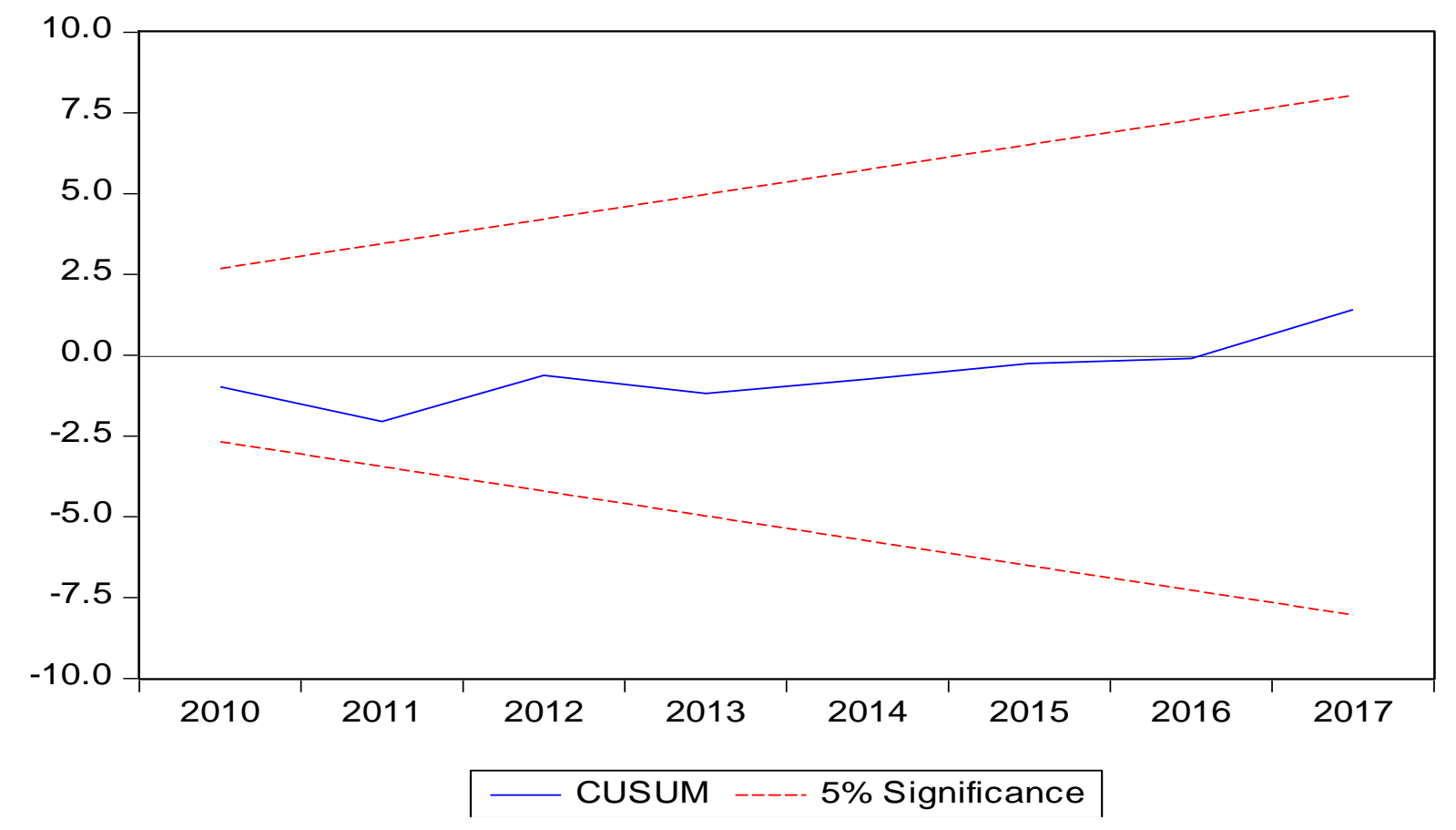

Fig. 1.

This tests show that there is no serial correlation and no problem of heteroscedasticity in the figure. The figure confirms that the curve is within the critical interval at 5\% significance. This means that coefficients are stable over the research period and the model is valid.

5. Conclusion. We collected the small database and observations from 1998 and 2017. To be more exact, we used to verify the ARDL approach and testing relationship long run and short run cointregration, our empirical results indicate the negative impact of total number of taxpayers on the forecasted total budget revenues and the unidirectional long run from cointregration total number of tax payers to forecasted total budget revenues. This study finding show that the hypothesis for the relationship between the numbers of registered company and forecasted total budget revenues in Uzbekistan. More specifically, in the long-run relationship there is a directional relationship between the numbers of registered company 
and forecasted total budget revenues. The numbers of registered company enables Uzbekistan to benefit from technology transfer that helps to invest more in the small business sector.

\section{REFERENCES}

1. Pesaran, M.H., Pesaran, B., 1997. Working with Microfit4.0: Interactive Econometic Analysis. Oxford University Press, Oxford.

2. Pesaran, M.H., Shin, Y., Smith, R.J., 2001. Bounds testing approaches to the analysis of level relationships. J. Appl. Econ. 16, 289-326

3. Robert F. Engle; C. W. J. Granger., 1987. Cointegration and Error Correction: Representation, Estimation, and Testing. Econometrica, Vol. 55, No. 2. pp. 251-276

4. Johansen, S., 1988, "Statistical Analysis of Cointegration Vectors," Journal of Economic Dynamics and Control, Vol. 12, No. 2-3, pp. 231-254.

5. Johansen, S.,1991, "Estimation and Hypothesis Testing of Cointegration Vectors in Gaussian Vector Autoregressive Models," Econometrica, Vol. 59, No. 6, pp. 1551-1580.

6. Johansen, S., and Juselius, K., 1990, "Maximum Likelihood Estimation and Inference on Cointegration with Applications to the Demand for Money," Oxford Bulletin of Economics and Statistics, Vol. 52, No. 2, pp. $169-210$.

7. Ramazan S., Bradley T. Ewing., Ugur S., 2008, "The relationship between disaggregate energy consumption and industrial production in the United States: An ARDL approach" Energy Economics, Vol. 30 No.1, pp. 2302-2313

8. Bruce M., 2006, "Causality between economic growth and immigration: An ARDL Bounds testing approach" Economics Letters Vol.90, No.1, pp. 72-76

9. Nicholas M., 2009, "Energy consumption and economic growth nexus in Tanzania: An ARDL bounds testing approach" Energy Policy, Vol.37, No.1, pp.617-622

10. Riadh B., Mohamed A., Hatem J., 2017, "Renewable energy consumption, International trade, oil price and economic growth inter-linkages: The case of Tunisia", Renewable and Sustainable Energy Reviews, Vol.76, No.1, pp.620-627

11. Soo K., Chung Y., Robert M., 2017, "Re-examining Foreign Direct Investment, Exports, and Economic Growth in Asian Economies Using a Bootstrap ARDL Test for Cointegration" Journal of Asian Economics, Vol., 51, No.1, pp.12-22

12. Mohaddes, K., Raissi, M., Weber, A., 2017 "Can Italy grow out of its NPL overhang? A panel threshold analysis" Economics Letters, Vol.159, No.1, pp.185-189

13. Mohammad M., Mohammad A., 2017 "Carbon emissions, energy consumption and industrial growth in Bangladesh: Empirical evidence from ARDL cointegration and Granger causality analysis" Energy Policy, Vol.110, No.1, pp.600-608 